\title{
Teaching NeuroImages: The heart sign in a patient with apparent locked-in syndrome
}

Ylec M. Cardenas, MD, Aparna Prabhu, MD, MRCP, and Yan Zhang, MD, PhD

Neurology ${ }^{\circledR}$ 2018;91:e2102-e2103. doi:10.1212/WNL.0000000000006579

Correspondence

Dr. Cardenas

cardenay@einstein.edu

Figure Radiologic imaging features of the patient

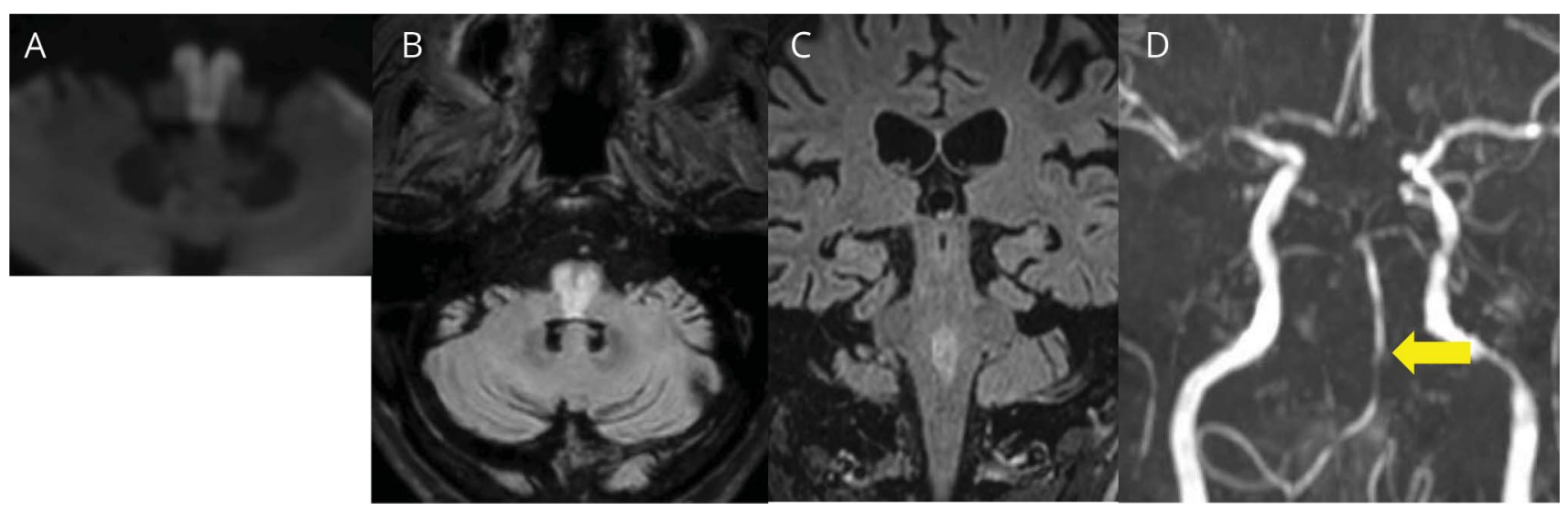

(A) Diffusion-weighted imaging and (B) axial fluid-attenuated inversion recovery image show an infarction in the bilateral paramedian medulla, with evidence of pontine extension involving the floor of the 4th ventricle (C). (D) Magnetic resonance angiography reconstruction demonstrates occlusion of the left vertebral artery and areas of thrombosis and stenosis at the left vertebrobasilar junction.

An 85-year-old man presented with 48 hours of recurrent vomiting and vertigo with rapidly progressive dysphagia and quadriplegia. MRI-magnetic resonance angiography showed a paramedian medullary infarct (figure, A-C), known as the heart sign, hallmark of this rare posterior circulation stroke caused by occlusion of the anterior spinal artery (figure, D). Clinical presentation is determined by anteroposterior extension. ${ }^{1}$ Associated with quadriplegia, tongue weakness, and sensory loss, localized to the pyramidal tracts, hypoglossal nucleus, and medial lemniscus respectively, ${ }^{2}$ our case correlates with pontine extension evidenced by recurrent vomiting, facial diplegia, and horizontal ophthalmoplegia, with the involvement of the area postrema, facial colliculus, and paramedian-pontine-reticular formation.

\section{Study funding}

No targeted funding reported.

\section{Disclosure}

The authors report no disclosures relevant to the manuscript. Go to Neurology.org/ $\mathrm{N}$ for full disclosures.

\section{MORE ONLINE}

$\rightarrow$ Teaching slides

links.lww.com/WNL/

A750 
Appendix 1 Author Contributions

\begin{tabular}{llll}
\hline Name & Location & Role & Contribution \\
\hline $\begin{array}{l}\text { Ylec M. } \\
\text { Cardenas, MD }\end{array}$ & $\begin{array}{l}\text { Albert Einstein Medical Center, } \\
\text { Philadelphia-Pennsylvania }\end{array}$ & Author & $\begin{array}{l}\text { Design and conceptualized study; acquisition of data, analysis, interpretation, } \\
\text { bibliographic review and drafted manuscript for intellectual content. }\end{array}$ \\
\hline $\begin{array}{l}\text { Aparna } \\
\begin{array}{l}\text { Prabhu, MD, } \\
\text { MRCP }\end{array}\end{array}$ & $\begin{array}{l}\text { Albert Einstein Medical Center, } \\
\text { Philadelphia-Pennsylvania }\end{array}$ & Author & Supervision and revision of manuscript. \\
$\begin{array}{l}\text { Yan Zhang, MD, } \\
\text { PhD }\end{array}$ & $\begin{array}{l}\text { Albert Einstein Medical Center, } \\
\text { Philadelphia-Pennsylvania }\end{array}$ & Author & Study concept and design, supervision and revision of manuscript. \\
\hline
\end{tabular}

\section{References}

1. Deshpande A, Chandran V, Pai A, Rao S, Shetty R. Bilateral medial medullary syndrome secondary to Takayasu arteritis. BMJ Case Rep 2013;2013:bcr0120125600.
2. Benito-Leon J, Alvarez-Cermeno J. Isolated total tongue paralysis as a manifestation of bilateral medullary infarction. J Neurol Neurosurg Psychiatry 2003;74: $1698-1699$. 


\section{Neurology}

Teaching NeuroImages: The heart sign in a patient with apparent locked-in syndrome Ylec M. Cardenas, Aparna Prabhu and Yan Zhang

Neurology 2018;91;e2102-e2103

DOI 10.1212/WNL.0000000000006579

This information is current as of November 26, 2018

Updated Information \& Services

References

Subspecialty Collections

Permissions \& Licensing

Reprints including high resolution figures, can be found at: http://n.neurology.org/content/91/22/e2102.full

This article cites 2 articles, 1 of which you can access for free at: http://n.neurology.org/content/91/22/e2102.full\#ref-list-1

This article, along with others on similar topics, appears in the following collection(s):

All Cerebrovascular disease/Stroke

http://n.neurology.org/cgi/collection/all_cerebrovascular_disease_strok e

\section{Embolism}

http://n.neurology.org/cgi/collection/embolism

MRI

http://n.neurology.org/cgi/collection/mri

Information about reproducing this article in parts (figures,tables) or in its entirety can be found online at:

http://www.neurology.org/about/about_the_journal\#permissions

Information about ordering reprints can be found online:

http://n.neurology.org/subscribers/advertise

Neurology ${ }^{\circledR}$ is the official journal of the American Academy of Neurology. Published continuously since 1951, it is now a weekly with 48 issues per year. Copyright @ 2018 American Academy of Neurology. All rights reserved. Print ISSN: 0028-3878. Online ISSN: 1526-632X.

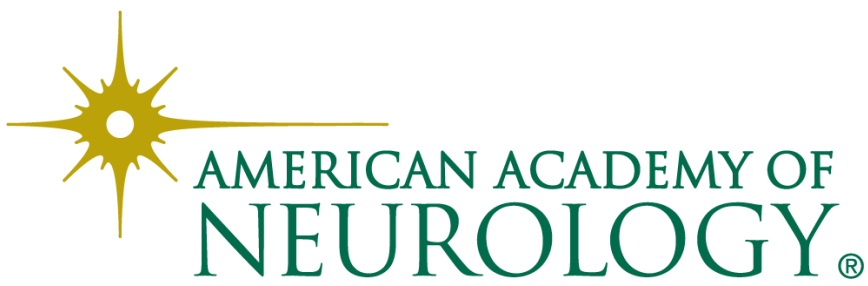

